\title{
Belas Kasih Allah dalam Kematian Kristiani Menurut Karl Rahner
}

\author{
Nemesius Pradipta a,1 \\ ${ }^{a}$ Universitas Sanata Dharma Yogyakarta \\ ${ }^{1}$ nemesius.ii@gmail.com
}

\section{Keywords:}

Kematian,

Karl Rahner,

milenial,

belas kasih,

rahmat,

Yesus Kristus,

teologi

transendental.

\begin{abstract}
Death is a definite and inevitable reality of life. Every human being will be faced with the reality of death regardless of the circumstances of their lives. Karl Rahner assumes that in a Christian perspective the reality of death must be interpreted in its union with God's own love shown through the death and resurrection of His Son, Jesus Christ. Death in Karl Rahner's thought is based on Self-communication of God (Selbstmitteilung Gottes) which appears in the death and resurrection of Jesus Christ to redeem mankind from sin and death. The death of Christ has changed the meaning of human death no longer as a punishment for sin, but as participation in the love of God who wants to save human beings.
\end{abstract}

\section{PENDAHULUAN}

Kematian adalah salah satu peristiwa kehidupan manusia yang tidak dapat dihindari. Semua makhluk hidup tak terkecuali manusia akan mengalami dan menghadapi kematian mereka sendiri secara personal. Sekeras apapun manusia berusaha mempertahankan hidupnya, namun pada akhirnya mereka tetap akan mengalami kematian. Berhadapan dengan peristiwa ini, setiap manusia memiliki cara yang berbeda-beda dalam memahami dan menghayati kematian mereka. Sudah sejak awal peradaban manusia, manusia telah berulang kali mencoba merefleksikan mengapa terjadi kematian dan nilai apa yang dapat diambil dari kematian.
Manusia dengan seluruh kemampuan akal budinya mencoba memahami dan memperoleh aneka macam jawaban mengenai arti sebuah kematian. Namun, rupa-rupanya memahami peristiwa kematian bukanlah perkara yang mudah. Manusia lebih mudah melihat kematian sebagai kutuk dari pada berkat. Kematian menjelma menjadi musuh kehidupan yang sebisa mungkin dihindari dan harus dikalahkan.

Dalam ajaran kristiani, ide tentang kematian tidak dapat dilepaskan dari karya keselamatan Allah. Dengan pelbagai pendasaran biblis dan kisah-kisah dalam tradisi kristiani, orang menghadirkan sejumlah re- 
fleksi tentang kematian dan mengkaitkannya dengan peristiwa penderitaan Yesus Kristus yang mati di salib dan kemudian bangkit dari kematian. Umat kristiani percaya bahwa Yesus Kristus telah mati di salib dan kemudian bangkit dari kematian setelah dimakamkan selama tiga hari. Peristiwa wafat dan kebangkitan itu kemudian direfleksikan oleh umat kristiani sebagai jalan keselamatan yang ditawarkan Allah kepada manusia (LG 3).

Dalam upaya mendalami kematian, penulis tertarik dengan pemikiran Karl Rahner dalam merefleksikan realitas kematian. Rahner percaya bahwa kematian merupakan fenomena alamiah, siapa saja akan mengalami kematian. Namun, ia percaya bahwa kematian bukanlah akhir sebuah kehidupan. Kematian bukanlah sekadar terpisahnya jiwa dan badan, melainkan dimaknai sebagai ambil bagian dalam kematian Kristus. ${ }^{1}$ Melalui kematian Kristus, rahmat keselamatan Allah hadir dalam kematian manusia.

Dalam pengerjaan karya tulis ini, penulis akan berfokus untuk mengerti ide Karl Rahner mengenai realitas kematian dalam perspektif kristiani. Akan tetapi penulis menyadari bahwa Rahner memiliki banyak tulisan dengan berbagai macam tema yang berbeda. Oleh karena itu, penulis hendak membatasinya hanya pada tulisan-tulisan Rahner yang berkaitan dengan tema seputar kematian, khususnya dalam buku On The Theology Of Death. Hal ini bertujuan untuk memberikan batasan yang jelas sehingga pengerjaan karya tulis ini semakin mudah dipahami. Walaupun demikian, penulis tidak menutup kemungkinan atas adanya sumber-sumber bacaan lain mengenai eskatologi dan teologi kematian berkaitan dengan pemikiran Rahner ini.
Adapun penulisan ini memiliki beberapa tujuan, yakni: Pertama, menemukan dan memaknai realitas kematian dalam iman katolik dengan bertitik tolak dari pemikiran Rahner. Kedua, melalui metode hermeneutika ini, penulis berharap dapat menyumbangkan refleksi dan relevansi teologis yang berguna bagi Gereja dalam memaknai realitas kematian.

Tulisan ini merupakan studi pustaka yang menggunakan metode hermeneutika Gadamer. ${ }^{2}$ Bagi Gadamer, hermeneutik merupakan proses berulang-ulang yang mana setiap proses memahami tidak pernah bisa berdiri sendiri sehingga selalu melibatkan pemahaman dasar lainnya sampai diperoleh pemahaman baru. Oleh karena itu dalam hermeneutika Gadamer, teks dapat dipahami dengan cara memahami cakrawala (horizon) masa silam melalui cakrawala kita di masa kini (Horizontverschmelzung). Melalui metode hermeneutik ini, penulis akan memadukan antara cakrawala teks, dengan cakrawala penulis. ${ }^{3}$ Cakrawala teks diperoleh dengan menginterpretasikan tulisan-tulisan Rahner tentang kematian yang ada dalam berbagai karyanya, khususnya dari bukunya yang berjudul On the Theology of Death. Melalui analisa itu, penulis mencoba mencari gagasan-gagasan pokok sebagai sebuah batu loncatan untuk menemukan dan merefleksikan bagaimana kematian direfleksikan dan dijelaskan oleh Rahner. Setelah itu, cakrawala teks akan dipadukan dengan cakrawala penulis yang banyak dipengaruhi oleh situasi dan kondisi dunia saat ini, khususnya perkembangan ilmu pengetahuan dan teknologi. Dengan demikian, melalui studi hermeneutik ini penulis dapat mengerti dan memahami teologi tentang kematian sehingga pemikiran Rahner masih bisa diterapkan dalam konteks dunia saat ini. 


\section{KONTEKS KEHIDUPAN KARL RAHNER}

\section{Riwayat Hidup Karl Rahner}

Rahner dilahirkan pada tanggal $5 \mathrm{Ma}-$ ret 1904 di Freiburg im Breisgau, Jerman. ${ }^{4}$ Rahner bergabung dengan Serikat Yesus ketika berusia 18 tahun dan menjalani pendidikan sebagai seorang Yesuit. ${ }^{5}$ Selama menjalani masa pendidikannya ia mempelajari filsafat Skolastik dan filsafat Jerman Modern. Rahner sangat mengagumi pemikiran Immanuel Kant (1724-1804) dan dua tokoh Thomistik kontemporer, yakni seorang Jesuit Belgia Joseph Maréchal $(1878-1944)^{6}$ dan seorang Jesuit Prancis Pierre Rousselot (1878-1915). ${ }^{7}$ Ketiga tokoh ini sangat mempengaruhi cara pandangnya dalam membaca tulisan-tulisan Thomas Aquinas (1225-1274). ${ }^{8}$ Ia juga mendalami pemikiran Ignatius Loyola sebagai pendiri serikat serta mempelajari neo-skolastik.

Karl Rahner memperoleh gelar doktoralnya (1936) dengan menyelesaikan disertasinya yang dalam bahasa Inggris berjudul "The Origin of the Church as Second Eve from the side of Christ the Second Adam". Setelah memperoleh gelar doktoralnya, Rahner mulai mengajar di Innsbruck dan tak lama setelah itu, bahan disertasinya yang ditolak di Freiburg diterbitkan dengan judul Geist in Welt (Spirit in the World). Setelah Perang Dunia II usai pada tahun 1948, ia kembali mengajar di fakultas teologi di Innsbruck sampai dengan masa pensiunnya tahun $1971 .{ }^{9}$

Selama di Innsbruck, Rahner mulai aktif menghasilkan banyak tulisan. Pada masa ini, ada beberapa karyanya yang mulai dibukukan, namun tulisan-tulisannya banyak disensor dan gerakannya sebagai seorang teolog dibatasi. Akan tetapi, secara tiba-tiba Rahner dipanggil oleh Gereja untuk mengi- kuti Konsili Vatikan II (1962-1965) sebagai salah seorang ahli teologi. Di dalam Konsili Vatikan II, Rahner bersama dengan seluruh teolog lainnya bertugas sebagai teolog resmi (peritus) yang berkumpul untuk membahas permasalahan aktual dunia demi menentukan arah Gereja ke depannya. Rahner meninggal pada tanggal 30 Maret 1984 dan dimakamkan di Gereja Jesuit di Innsbruck, Austria. ${ }^{10}$

\section{Konteks Historis}

Untuk memahami teologi Rahner, konteks Eropa di mana Rahner hidup, merupakan locus theologicus. Teologi Rahner tidak dapat dipisahkan dari situasi dan kondisi yang telah ataupun sedang dialaminya. Sebagai seorang teolog yang lahir di awal abad ke-20, Rahner hidup dalam situasi Eropa yang sedang mengalami modernisasi. Situasi ini terjadi karena dipengaruhi oleh modernisme yang sudah dimulai sekitar abad ke-17 dengan ditandai bangkitnya kesadaran akal budi manusia (rasionalisme) yang dikenal sebagai Enlightenment (Aufklärung). ${ }^{11} \mathrm{Di}$ Jerman sendiri, gerakan pencerahan yang lebih dikenal sebagai Aufklärung, dikembangkan oleh Leibniz dan Kant sampai berkembang pesat dan memberi pengaruh tersendiri terhadap perkembangan sosial dan politik. Semangat Enlightenment ini dianggap mampu membuka gagasan toleransi untuk mendamaikan orang Kristen melalui penerapan hukum positif, tatanan moral, dan perkembangan ilmu pengetahuan. ${ }^{12}$

Di dalam Gereja sendiri semangat modernisme tanpa sadar telah menghembuskan pembaruan baik dalam perkembangan ilmu teologi maupun dalam bidang sosial dan kultural. Berhadapan dengan situasi ini, Gereja yang pada masa itu bersikap hati-hati dengan perkembangan modernisme mendorong Paus Pius IX menerbitkan Ensiklik 
Syllabus Errorum (1864) yang memuat daftar kesalahan dari dunia modern yang harus ditolak Gereja. Penolakan ini berpuncak pada diadakannya Konsili Vatikan I (1869$1870)^{13}$ yang diprakarsai oleh Paus Pius IX.

Beberapa tahun kemudian, Paus Leo XIII menyadari betapa perlunya mempertemukan antara iman dan akal budi sebagai sarana untuk mendamaikan Gereja dengan modernitas. Karena itu, beliau mengeluarkan Ensiklik Aeterni Patri (1879) ${ }^{14}$ sebagai ajakan bagi Gereja Katolik untuk kembali menghidupkan semangat filsafat dan teologi Thomas Aquinas. ${ }^{15}$ Dengan diterbitkannya ensiklik ini, Gereja abad XIX memulai suatu sistem pendidikan yang dikenal sebagai neo-thomistik yang nantinya akan mempengaruhi pemikiran Rahner.

Rahner sebagai seorang teolog yang lahir dan hidup pada abad XX dipengaruhi oleh pemikiran filsafat modern dan teologi neo-thomisme. Lalu bagaimana hubungan keduanya dalam keseluruhan teologi Rahner? Di satu sisi, cara berpikir Rahner telah dipengaruhi oleh semangat Aufklärung yang menekankan pengolahan akal budi. Melalui karya-karyanya dapat diketahui bahwa Rahner berusaha menjelaskan ajaran Gereja secara rasional sehingga orang tidak jatuh pada spekulasi semata melainkan memperoleh pemahaman iman yang benar. Di sisi lain, pemikiran Rahner juga dipengaruhi oleh neo-thomisme yang wajib dipahami oleh setiap teolog Katolik saat itu.

Pada masa itu, ilmu pengetahuan dan teknologi telah berkembang pesat. Kematian sebagai sebuah realitas tidak lagi dipandang sebagai sebuah misteri kehidupan, melainkan menjadi bagian dari objek penelitian. Pada masa itu ada begitu banyak penemuan baru dalam ilmu kedokteran dan ilmu pengetahuan yang menjadi dasar hara- pan banyak orang dalam mempertahankan kehidupan dari serangan berbagai macam penyakit mematikan. Akibatnya, manusia lebih bergantung pada kemajuan ilmu pengetahuan melalui kehadiran dokter dari pada bergantung kepada Tuhan. Kematian kemudian menjadi ajang pertarungan antara ilmu pengetahuan dan Tuhan. Kematian menjadi tabu untuk dibicarakan karena kematian merupakan realitas kekalahan manusia yang dapat menimbulkan depresi dan penolakan. ${ }^{16}$

Selain itu, pecahnya perang besar yang menghantam Eropa menunjukkan kepada dunia betapa banyaknya orang mati dengan sia-sia. Peperangan seakan menunjukkan bahwa nyawa manusia sedemikian rendahnya. Akibatnya, kematian menjadi sebuah permasalahan eksistensi manusia dalam mempertanyakan kehidupannya. Manusia mulai mempertanyakan kembali makna kehidupan bila berhadapan dengan kematian. Manusia mulai menyalahkan Tuhan yang membiarkan orang mati dalam penderitaan. Dengan demikian, penulis melihat bahwa dalam merefleksikan kematian Rahner tidak saja berhadapan dengan masalah iman, tetapi juga dengan masalah moral sosial yang terjadi di tengah masyarakatnya.

\section{BELAS KASIH ALLAH DAN REALITAS KEMATIAN MENURUT KARL RAHNER}

Dalam upaya merenungkan belas kasih Allah dalam realitas kematian, Rahner merefleksikan bahwa kematian merupakan sebuah peristiwa yang secara nyata ada dan dialami oleh seluruh manusia. Bagi Rahner, kematian merupakan sesuatu yang terjadi di sini dan saat ini. Akan tetapi, kematian tidak melulu dimaknai secara biologis tetapi juga secara spiritual. ${ }^{17}$ Karena itu, eksistensi manusia dalam antropologi kristiani 
pada hakikatnya sudah dipastikan untuk mengalami kematian dan terbuka pada misteri kematian itu sendiri. Oleh karena itu, kajian teologis ini bukan untuk menegaskan bahwa manusia pasti mati, melainkan untuk memaknai bagaimana manusia sebagai pribadi menerima kematian sebagai bagian dari realitas yang harus dihadapinya. ${ }^{18}$

\section{Kematian Bersifat Universal dan Berdampak Menyeluruh}

Kematian secara umum dimaknai sebagai sebuah peristiwa yang menyentuh manusia dalam totalitasnya. ${ }^{19}$ Teologi kematian Rahner dibangun berdasarkan sebuah kesadaran bahwa kematian merupakan sebuah peristiwa yang secara nyata ada dan dialami oleh seluruh manusia. Semua orang dapat menangkap pengalaman kematian melalui indera mereka yang terjadi dalam kehidupan mereka sehari-hari.

Rahner melihat bahwa universalitas kematian merupakan proposisi mutlak dari iman kita. ${ }^{20}$ Universalitas kematian pertama-tama mesti dipahami dalam sudut pandang iman kristiani yang melihat manusia sebagai mahluk spiritual dan layak untuk berelasi dengan penciptanya. ${ }^{21}$ Karena itu, universalitas kematian harus dipahami sebagai sebuah prinsip absolut dan mendasar yang harus dipegang dari iman kita, yakni bahwa seluruh manusia pasti mengalami kematian (bdk. Kej 3:19; Rom 6:5; 1 Kor 15:22).

Selain itu, Rahner beranggapan bahwa kematian merupakan sebuah realitas dari luar manusia yang menerobos eksistensi manusia dan berdampak secara total. ${ }^{22} \mathrm{Da}-$ lam Kitab Kejadian dikatakan bahwa manusia adalah makhluk yang diciptakan dari debu tanah dan Allah menghembuskan nafas hidup ke dalam hidungnya (bdk. Kej 2:7). Pernyataan ini hendak menunjukkan bahwa eksistensi manusia merupakan kesatuan dua unsur, yakni kesatuan materi dan rohani, serta kesatuan antara makhluk duniawi sekaligus juga makhluk spiritual yang semuanya merupakan satu kesatuan yang tidak dapat dipisahkan. ${ }^{23}$ Artinya, kematian merupakan realitas kehidupan yang menyerang dan menghancurkan eksistensi manusia secara total. Dengan demikian, kematian sebagai sebuah peristiwa kehidupan yang berdampak pada keseluruhan manusia, jiwa dan badannya, bukanlah sekadar peristiwa material dan biologis semata, melainkan juga berdampak pada jiwanya. Dengan kata lain, kematian tidak hanya mempengaruhi keadaan badan manusia, tetapi juga meliputi kesadaran diri (self-awareness), sisi manusiawinya (personhood), kebebasan, tanggungjawab, kasih, dan keimanannya (faithfulness) sebagai bagian dari ungkapan kebebasan jiwanya. ${ }^{24}$

\section{Keikutsertaan dalam Kematian Kristus}

Rahner berpendapat bahwa kematian manusia hanya dapat dimaknai secara penuh apabila diterangi oleh kematian Kristus sendiri. Berkaitan dengan kematian Kristus ini, Rahner mengatakan bahwa:

Sang Sabda, melalui inkarnasi dalam rahim Maria, menjadi sama dengan kita. Dari sini, dalam pengertian yang sebenarnya, Kristus mati dalam kematian kita. Dia mengalami penderitaan sebagaimana manusia jatuh karena Adam.... Tetapi jika Dia menjadi sama dengan kita kecuali dalam hal dosa, seperti yang diwartakan Surat kepada Orang Ibrani, maka Dia juga menjadi seperti kita dalam kematian. ${ }^{25}$

Melalui pernyataan ini Rahner hendak menunjukkan bahwa Kitab Suci juga mewartakan bahwa Yesus juga mengalami kematian yang sama seperti kita. Namun, ke- 
tika Rahner berbicara mengenai kematian Kristus, ia memiliki pengertian tidak saja kematian sebagaimana yang dialami oleh manusia pada umumnya, tetapi juga dimaknai oleh manusia sebagai puncak penebusan dalam kematian-Nya. ${ }^{26}$ Melalui kematian Kristus, kita dapat memahami bahwa karya penebusan manusia tidak hanya terjadi melalui pengurbanan atas tubuh dan darah-Nya yang telah diserahkan bagi manusia, tetapi juga terletak pada kesabaran dan ketaatan-Nya untuk menderita hingga wafat di kayu salib. Karena itu, kematian Yesus tidak hanya melunasi dosa manusia, tetapi juga menunjukkan bahwa penderitaan karena kematian merupakan perwujudan nyata dari dosa di dalam dunia. ${ }^{27}$

Lalu apa relasi antara kematian Kristus dengan kematian orang kristiani pada umumnya? Rahner berpendapat bahwa kematian kristiani dapat diimani sebagai mati bersama Kristus. ${ }^{28}$ Kitab Suci Perjanjian Baru mewartakan bahwa kematian kristiani berarti "mati di dalam Kristus". Artinya, jika kita mati dengan Dia, maka kita pun tidak akan mati lagi melainkan akan hidup dengan Dia (2 Tim. 2:11; Rom. 6:8). Hal ini juga senada dengan apa yang dikatakan oleh Yesus sendiri bahwa "setiap orang yang hidup dan yang percaya kepada-Ku, tidak akan mati selama-lamanya" (Yoh. 11:26). Dengan mengambil bagian dalam kematian Kristus, Rahner menjelaskan bahwa kita tidak hanya "mati di dalam Kristus", tetapi juga hidup di dalam Dia.

\section{Belas Kasih Allah dalam Kematian Kristus}

Bagi Rahner, kematian Kristus yang menyelamatkan manusia lebih dari sekadar tindakan yang menunjukkan ketaatan-Nya kepada kehendak Allah, tetapi juga memperlihatkan betapa besar cinta-Nya kepa- da manusia. ${ }^{29}$ Rahner berpendapat bahwa karya keselamatan manusia berpangkal dari belas kasih Allah sendiri yang sudah sejak awal menyertai kehidupan manusia melalui rahmat-Nya yang tidak kelihatan dan berpuncak dalam peristiwa Yesus Kristus. Rahner mengatakan bahwa "Rahmat terjadi secara fundamental dalam komunikasi diri Allah (Selbstmitteilung Gottes) yang memungkinkan manusia dalam kebebasannya, dengan iman, harapan, dan kasih untuk menerima Allah sebagaimana ditawarkan kepadanya."30

Lalu, bagaimana relasi antara kematian Kristus dengan belas kasih Allah dapat dijelaskan? Kitab Suci mewartakan bahwa "karena begitu besar kasih Allah akan dunia ini, sehingga Ia telah mengaruniakan AnakNya yang tunggal, supaya setiap orang yang percaya kepada-Nya tidak binasa, melainkan beroleh hidup yang kekal (Yoh 3:16)." Rahner melihat bahwa keselamatan merupakan perwujudan dari pemberian diri Allah kepada umat manusia. Keselamatan itu terjadi karena di dalam Kristus setiap manusia mengambil bagian dalam Allah dan karenanya mereka dikuduskan dan diselamatkan. Dalam situasi ini manusia dipanggil untuk bersatu dengan Allah di dalam kasih dan pengetahuan, yakni ketika manusia sebagai pribadi mengambil bagian dalam kodrat Ilahi. ${ }^{31}$ Karenanya, kodrat manusia tidak bersifat statis, ahistoris, dan tidak dapat berubah, melainkan sebagai sebuah realitas sejarah dari panggilan Allah dan tanggapan bebas manusia terhadap-Nya. Dengan kata lain, belas kasih Allah sebagai pemberian diri Allah berpuncak dalam kematian Kristus dan mengarah pada keselamatan universal.

\section{KEMATIAN DI ZAMAN MILENIAL}

Pada bagian ini, penulis secara khusus hendak menunjukkan penerapan dari fu- 
sion of horizon Gadamer sebagai bagian dari metode pengerjaan tulisan ini.Penulis akan memadukan teologi Rahner tentang kematian dengan konteks situasi zaman milenial dalam memaknai realitas kematian. Hal ini hendak menjelaskan dua hal, yaitu: (1). bagaimana Allah mengkomunikasikan diri-Nya dalam realitas kematian di zaman milenial ini. (2). Menjelaskan bagaimana realitas kematian merupakan bagian dari pengalaman integral manusia yang melalui pengalaman itu, manusia dapat mempelajari batas-batas eksistensinya sendiri sehingga mereka dapat mengetahui dengan lebih baik realitas kematian mereka sendiri ataupun orang lain.

Tulisan ini memang mengangkat zaman milenial secara umum sebagai bagian dari cakrawala penulis dalam pengerjaan tulisan ini, namun secara khusus penulis akan masuk ke dalam situasi umat Keuskupan Agung Jakarta dalam penerapannya. Walaupun umat Keuskupan Agung Jakarta tidak sepenuhnya generasi milenial, namun penulis berpendapat bahwa penggunaan istilah milenial untuk menunjuk pada situasi zaman ini sudah umum terjadi di Jakarta. Jakarta sebagai kota megapolitan telah didominasi generasi milenial dengan beragam perkembangan gaya hidup dan budayanya. Penggunaan istilah milenial juga sudah biasa digunakan dalam media cetak seperti Koran Kompas dan Majalah Tempo, maupun dalam media elektronik dan media sosial. Bahkan pada ARDAS KAJ 2016-2020, Keuskupan Agung Jakarta telah menerapkan reksa pastoral yang menyasar umat beriman yang telah dipengaruhi oleh budaya milenial ini. Misalkan saja dalam pertemuan Temu Pastoral (TEPAS) yang diadakan pada tanggal 21-24 Mei 2018 (Gelombang I) dan 28-31 Mei 2018 (Gelombang II), KAJ mengangkat tema-tema yang berhubungan dengan budaya milenial.

\section{Kematian sebagai Pengalaman}

Untuk memahami kematian dalam konteks zaman milenial pertama-tama kita harus menyadari bahwa kematian merupakan sebuah pengalaman manusiawi. Kematian adalah pengalaman yang nyata ada dan dialami oleh semua orang. Tidak ada seorang pun yang mengetahui secara pasti di mana dan kapan manusia akan mati, akan tetapi setiap orang tahu dengan pasti bahwa suatu saat mereka akan mengalami kematian. Berkaitan dengan kematian sebagai pengalaman, maka kita perlu memahami terlebih dahulu apa itu "pengalaman". Penulis mencoba mengartikan apa itu pengalaman sebagaimana yang dijelaskan oleh Gadamer. Gadamer menerangkan bahwa "pengalaman di sini adalah sesuatu yang merupakan suatu bagian dari kodrat historis manusia". ${ }^{32}$ Kemudian ia melanjutkan bahwa "pengalaman adalah pengalaman keterbatasan manusia”. ${ }^{33}$ Mengenai pengertian pengalaman Gadamer mengatakan:

Dengan demikian pengalaman ada-
lah pengalaman keterbatasan manusia.
Orang yang sungguh berpengalaman
adalah orang yang sadar akan hal ini,
yang mengetahui bahwa ia bukanlah tuan
bagi waktu maupun masa depan. Orang
yang berpengalaman mengetahui keter-
batasan-keterbatasan dari semua prediksi
dan ketidakpastian dari semua rencana.
Di dalam dirinya disadari nilai-kebenaran
dari pengalaman. Jika itu adalah karakter-
istik dari setiap fase proses pengalaman
bahwa orang yang berpengalaman mem-
peroleh suatu keterbukaan baru terhadap
pengalaman baru, hal ini pastilah gagasan
yang benar dari pengalaman yang leng-
kap. ${ }^{34}$

Dengan demikian, ketika seseorang berhadapan dengan pengalaman kematian, ses- 
eorang disadarkan bahwa manusia bukanlah penguasa waktu. Pada akhirnya pengalaman kematian mengajarkan manusia akan keterbatasan hidup dan ketidakpastian akan masa depannya. ${ }^{35}$ Akan tetapi, kesadaran akan pengalaman kematian justru membantu manusia untuk menyadari nilai pengalaman yang sebenarnya. ${ }^{36}$ Melalui pengalaman itu, manusia menjadi memahami keterbatasannya dan dapat menemukan batas-batas kekuatan dan pengetahuan diri akan pengalaman mereka sendiri ataupun orang lain, sehingga pengalaman itu mendorong perasaan baru dan pemahaman baru atas pengalaman yang dihadapinya. ${ }^{37} \mathrm{Han}$ ya dengan menyadari bahwa kematian merupakan sebuah pengalaman hidup manusia, seseorang dapat memahami dan memaknai kematian secara baru.

\section{Generasi Milenial dan Tantangannya}

Memasuki masa milenium baru ini, muncul sebuah generasi baru yang kerap dikenal sebagai generasi milenial. ${ }^{38}$ Generasi milenial atau yang juga sering disebut sebagai generasi Y menunjuk pada kelompok demografi setelah generasi $\mathrm{X}$ yang lahir pada tahun 1980 sampai tahun 1999. ${ }^{39}$ Generasi ini merupakan generasi pertama yang melalui masa dewasa dan terhubung langsung dengan masa milenium baru. Generasi milenial digambarkan sebagai generasi yang percaya diri, ekspresif, bebas, optimis dan terbuka terhadap perubahan. Secara umum, karakteristik generasi milenial ditandai dengan peningkatan penggunaan teknologi digital dan media sosial sehingga mereka selalu terhubung dengan media. Mereka memiliki beragam cara mengekspresikan diri, kurang religius, menyukai hal-hal yang praktis dan cepat, berpendidikan tinggi, dan lebih toleran dibandingkan generasi-generasi sebelumnya.
Di tengah arus globalisasi dewasa ini, tantangan besar yang dihadapi masyarakat milenial ialah sekularisme yang ditandai dengan gaya hidup yang semakin materialistis, konsumeristis, dan individualistis. Sekularisme mendorong agar negara sebaiknya tidak dilibatkan dalam masalah agama maupun sebaliknya. ${ }^{40}$ Dengan demikian, aktivitas dan keputusan publik, khususnya politik, tidak dipengaruhi atau dikuasai oleh keyakinan atau praktik keagamaan tertentu sehingga setiap orang dapat memperoleh pelayanan publik yang sama dan diperlakukan secara setara.

Dewasa ini, perkembangan ekonomi global telah menjadikan konsumerisme sebagai bagian dari budaya milenial. ${ }^{41}$ Konsumerisme terjadi karena garis antara informasi, hiburan, dan promosi produk telah menjadi kabur sehingga hal ini memanipulasi perilaku manusia dan membangkitkan keinginan untuk membeli dan menghamburkan uang mereka dalam berbelanja. ${ }^{42}$ Gaya hidup semacam ini bertujuan untuk menikmati produk sebanyak mungkin tanpa memikirkan apakah benda-benda yang mereka beli itu berguna atau bermanfaat. Sikap konsumeristis dapat mendorong orang untuk selalu mengikuti tren supaya mereka memperoleh pengakuan di mata orang lain.

Ketika kita memikirkan tentang kematian dalam konteks masyarakat saat ini, sebagian besar orang ingin menghindari kematian dari pengalaman harian mereka. Banyak orang yang menghindari membicarakan tentang kematian. Walaupun kemajuan teknologi dan ilmu pengetahuan telah memperpanjang batas hidup manusia dari pada nenek moyang kita, namun realitas harian kita tetap menunjukkan betapa rentannya manusia terhadap kematian. 
Secara kultural, sekularisme tidak saja melemahkan kepercayaan orang-orang di kota-kota besar akan peran agama dalam menghadapi kematian, tetapi juga mempengaruhi cara mereka dalam memaknai kematian. Pada saat ini, orang sakit cenderung mengutamakan kehadiran dokter dari pada kehadiran pemimpin agama. Kalau beberapa waktu yang silam kebanyakan orang mengalami kematian di rumah mereka sendiri dengan dikelilingi oleh keluarga dan para sahabatnya, kini kebanyakan orang mengalami kematian di rumah sakit dengan dikelilingi oleh mesin yang menopang hidup mereka. Kalau dulu para orang tua menunjukkan kepada anak-anak mereka bagaimana menghormati orang yang mendekati ajal dan bagaimana bersikap dalam menghadapi kematian, kini sejumlah besar orang dalam budaya kita justru dijauhkan dari kebiasaan semacam itu. Akibatnya, masyarakat milenial tidak terbiasa berhadapan dengan pengalaman kematian sehingga realitas itu menjadi asing bagi pengalaman mereka. Maka wajarlah bila mereka tidak mengetahui bagaimana menghadapi rasa duka maupun bersimpati dengan orang yang sedang berduka. Hal ini senada dengan apa yang dikatakan oleh Fulton Sheen:

Sangatlah sulit menyakinkan orang-orang modern mengenai kematian karena mereka tidak ingin mendengar bahwa pada suatu titik tertentu hidup akan berakhir. Mereka tidak ingin menghadapi kenyataan akan adanya akhir hidup manusia. Apakah anda menyadari bahwa pikiran orangorang modern canggung dalam menghadapi kematian? Mereka tidak mengetahui cara mengungkapkan rasa simpati karena mereka berkonsentrasi pada keadaan sebelum kematian, bukan pada gagasan-gagasan tentang hidup kekal yang seharusnya ada dalam realitas kematian. ${ }^{43}$
Mengapa hal ini terjadi? Zachary Hayes dalam tulisannya yang berjudul Theology of Death mengatakan bahwa keadaan ini berkaitan dengan gagasan menguasai kematian melalui kemajuan teknologi. ${ }^{44} \mathrm{Ke}-$ majuan teknologi telah mengubah kultur manusia dalam berhadapan dengan reallitas kematian. Melalui kehadiran rumah sakit, setiap orang berharap agar hidup mereka dapat diperpanjang untuk beberapa bulan, beberapa minggu, ataupun beberapa hari. Akibatnya, kematian dilihat sebagai sebuah kegagalan perawatan medis daripada sebagai konsekuensi dari kehidupan. Beliau mengatakan: "Kematian dianggap hampir sebagai penghinaan terhadap kemampuan budaya teknologi kita. Jadi, godaan umum adalah menggunakan sarana apa pun yang tersedia untuk memperpanjang hidup tanpa mempedulikan hasil akhirnya." ${ }^{45}$ Pada akhirnya, kemajuan teknologi telah menyebabkan kematian dirasakan sebagai sesuatu yang tidak wajar, selalu menyedihkan, dan sesuatu yang tidak bisa dikendalikan.

\section{Gereja Keuskupan Agung Jakarta (KAJ)}

Keuskupan Agung Jakarta (selanjutnya disingkat: KAJ) merupakan sebuah wilayah gerejawi yang terletak di ibu kota Negara Kesatuan Republik Indonesia yang teritorial pelayanannya mencakup daerah Jakarta, Bekasi, dan Tangerang. Secara umum, konteks konkret dari KAJ tidak dapat dipisahkan dari keadaan Jakarta itu sendiri. Sebagai ibu kota negara dan kota terbesar di Indonesia, Jakarta merupakan sebuah kota megapolitan yang memiliki jumlah penduduk sekitar 10,4 juta jiwa. ${ }^{46}$ Selain itu, Jakarta juga merupakan pusat pemerintahan dan bisnis sehingga menyebabkan semua hal yang berhubungan dengan perkembangan politik, ekonomi, sosial, dan budaya terjadi di kota ini setiap harinya. 
Secara politik dan ekonomi, Jakarta menjadi salah satu kota terpenting tidak hanya di Indonesia, tetapi juga di Asia Tenggara. Jakarta menjadi kancah perpolitikan di Indonesia dan menjadi pusat bisnis yang menyebabkan 70\% perputaran uang di Indonesia terjadi di sana. ${ }^{47}$ Secara sosio-budaya, Jakarta adalah kota multikultural. Gemerlap ibu kota telah menarik banyak orang dengan beragam budaya, etnis, suku, dan negara yang saling menawarkan kekhasan dari masing-masing budaya mereka. Selain itu, beragam agama dan aliran kepercayaan juga tumbuh di sini. Dengan demikian, keragaman ini juga mendorong masuknya budaya baru yang lebih dikenal sebagai budaya populer (Pop-Culture). Sebagai kota megapolitan, Jakarta ditunjang oleh perkembangan ilmu pengetahuan dan teknologi modern yang mendorong Jakarta memasuki era globalisasi. Oleh karena itu, dari sekian banyak tantangan yang muncul, ada beberapa tantangan yang diperkirakan memiliki dampak yang paling besar seiring dengan perkembangan dan kemegahan Jakarta. Beberapa tantangan itu antara lain: kesenjangan sosial, tantangan sosio-politik, merajalelanya korupsi, intoleransi, krisis makna generasi muda, dan berkembangnya sekularisme yang mendorong gaya hidup yang semakin materialistis, konsumeristis, dan individualistis. ${ }^{48}$

Jakarta juga di kenal sebagai kota kaum urban. Jakarta sebagai ibu kota negara sekaligus sebagai pusat pemerintahan telah mendorong perkembangan ilmu pengetahuan dan teknologi. Akibatnya, orang dari berbagai macam daerah memilih Jakarta sebagai kota tujuan untuk mencari pekerjaan. Mereka yang menetap ini merupakan kaum urban yang pada akhirnya menciptakan tatanan sosial baru karena mereka mem- bawa serta nilai-nilai dari budaya mereka ke Jakarta. Selain itu, banyak kaum urban yang datang ke Jakarta adalah usia produktif. Oleh karena itu, ekspansi periklanan dan pemasaran yang ditopang oleh kekuatan media telah mendorong orang untuk mengkonsumsi, serta lahirnya budaya populer modern yang memuja konsumerisme, hedonisme, dan individualisme. ${ }^{49}$

Dalam konteks kematian, situasi Jakarta yang serba kompleks itu rupa-rupanya juga menyebabkan munculnya beberapa fenomena yang berkaitan dengan kematian yang kerap kali memberatkan masyarakat, khususnya mereka yang miskin, kecil, dan tersingkir. Penulis menemukan beberapa fenomena itu antara lain: mahalnya biaya pemakaman, tidak memungkinkannya mensemayamkan jenasah di rumah karena keterbatasan ruang dan sulitnya jalan masuk, terbatasnya lahan pemakaman di TPU, adanya calo dan pungli dalam proses pemakaman, iringiringan pengantar jenasah yang ugal-ugalan, bahkan penolakan mensholatkan jenasah karena berbeda pandangan politik.

Berhadapan dengan situasi semacam itu, Gereja KAJ memang telah mengadakan beberapa program yang sekiranya dapat membantu atau meringankan beban orang yang sedang berduka. Beberapa program itu misalkan saja dengan bekerjasama dengan Rumah Duka OASIS Lestari di Tangerang, bekerja sama dengan RS. St. Carolus dalam pelayanan rumah duka dan merawat jenasah, menggerakkan program Berkat St. Yusuf (BKSY) sebagai bentuk solidaritas untuk mereka yang sakit ataupun meninggal, menggerakkan paroki-paroki untuk menyediakan lahan pemakaman di TPU yang terjangkau, dan mengadakan iuran St. Yusuf di paroki-paroki untuk membantu umat yang meninggal. 


\section{SUMBANGAN TEOLOGI KARL RAHNER}

Kekhasan teologi Karl Rahner ialah menempatkan komunikasi diri Allah (Selbstmitteilung Gottes) sebagai pusat pemikirannya. Komunikasi diri Allah itu mewujud dalam rupa Allah-Putra sehingga setiap orang yang percaya kepada-Nya dapat beroleh belas kasih Allah yang sama. Demikian pula dalam merefleksikan tentang kematian, ia menempatkan pemberian diri Allah di dalamnya sehingga dalam kematian sekalipun orang tetap mampu menemukan belas kasih Allah. Pada bagian ini penulis hendak menunjukkan poin-poin teologis dari pemikiran Rahner yang sekiranya dapat menjadi salah satu perspektif dalam memaknai realitas kematian di zaman milenial ini, khususnya bagi Keuskupan Agung Jakarta. Diharapkan melalui sumbangan teologis ini, umat kristiani tetap memiliki pijakan dalam merefleksikan kematian dan dalam terang iman kristiani. Beberapa poin pemikiran Karl Rahner dalam berhadapan dengan realitas kematian yang masih relevan menurut penulis antara lain:

\section{Kematian sebagai Pengalaman Keseharian dan Universal}

Dalam On Christian Dying Karl Rahner menjelaskan bahwa "kematian tidak dapat dimaknai secara ketat dalam pengertian biologis atau psikologis semata, tetapi perlu dipahami dalam konteks pemahaman kristiani tentang eksistensi manusia."50 Selanjutnya ia menambahkan bahwa "manusia lebih dari sekadar perihal biologis semata karena manusia dianugerahi dengan kebebasan dan dengan kemampuan spiritual."51 Hal ini menunjukkan bahwa kematian adalah pengalaman eksistensial yang memungkinkan manusia berjumpa dengan inti dirinya. Pada kenyataannya banyak orang takut berjumpa dengan inti dirinya karena manusia dihadapkan pada kerapuhan dirinya. Masalahnya, dunia milenial cenderung mendorong manusia untuk merasa diri mampu mengatasi segalanya, namun pada kenyataannya, manusia tetap tidak mampu memahami kematiannya sendiri. Sebaliknya, mereka justru memandang realitas kematian sebagai pengalaman kerapuhan dan pengalaman kesedihan, sehingga pasti ditolak! Oleh karena itu, Rahner mencoba menunjukkan bahwa manusia dapat memahami kematian dengan cara memaknai kematian sebagai pengalaman keseharian.

Bagi Rahner, pengalaman kematian adalah pengalaman "keseharian manusia". ${ }^{52}$ Artinya, setiap orang akan menjumpai atau mengalami kematian dalam pengalaman hidup sehari-hari. Kematian dikatakan sebagai pengalaman keseharian (fenomena alamiah) karena kita dapat mengindrai pengalaman itu. Kita bisa melihat mayat orang yang membujur kaku, melihat orang yang merana kesakitan dan tidak berdaya menghadapi ajal, kita juga bisa merasa sedih, kecewa, dan marah kepada Tuhan karena orang yang kita kasihi meninggal. Karena itu, jika realitas kematian dapat dipandang sebagai sebuah pengalaman keseharian manusia, maka hal utama dan pertama yang perlu disadari ialah bahwa kematian itu sendiri bersifat universal. ${ }^{53}$ Artinya, semua manusia pasti mengalami kematian dan menjadikannya sebagai bagian dari pengalaman keseharian mereka sendiri.

Rahner beranggapan bahwa karena kematian adalah pengalaman eksistensial yang memungkinkan manusia berjumpa dengan inti dirinya, maka pengalaman kematian juga merupakan bagian dari pengalaman transendental manusia. ${ }^{54}$ Melalui pengalaman transendental ini, keterbatasan pemahaman manusia dalam memaknai realitas 
kematian memungkinkannya terbuka pada misteri ilahi. Dengan demikian, pengalaman transendental inilah yang memampukan manusia untuk memahami kematian dari kacamata imannya dan melihatnya sebagai bagian dari pewahyuan Allah. ${ }^{55}$ Karena itu, inti dari memahami pengalaman kematian adalah soal pemberian diri. Baik sebagai pemberian diri Allah kepada manusia, maupun sebagai pengalaman pemberian diri atau penyerahan total dari pihak manusia kepada penyelenggaraan Ilahi. Dengan demikian, orang kristiani diharapkan mampu melihat pengalaman kematian sebagai bagian dari pewahyuan Allah ke dalam pengalaman konkret manusia.

Sebaliknya, masyarakat yang tinggal di kota besar cenderung memandang kematian sebagai pengalaman semata, namun tidak mampu memaknainya. Hal ini disebabkan karena dunia moderen menawarkan banyak hal baru untuk menyembunyikan kematian dalam realitas kehidupan mereka. Di sisi lain, kesadaran akan keterbatasan hidup manusia tidak dipakai untuk memaknai kehidupan, melainkan untuk bersenang-senang. Mereka mudah lari dan tenggelam dalam arus informasi, perkembangan teknologi, dan dunia hiburan untuk menutupi kekosongan dan kerapuhan diri mereka. Akibatnya, banyak orang yang mengalami krisis makna dan krisis iman.

Dalam situasi semacam ini, pemikiran Rahner dapat menjadi sebuah alternatif dalam memaknai kehidupan berhadapan dengan realitas kematian. Pemahaman bahwa kematian bersifat universal dapat menjadi sarana bagi masyarakat di kota besar seperti Jakarta untuk memaknai kematian. Dalam hal ini, Gereja memiliki peran dalam memberikan kesadaran bahwa setiap kehidupan itu bernilai dan layak untuk dihidupi. Ge- reja dapat menjadi pewarta bahwa dibalik realitas kematian yang seakan tanpa makna itu, ada Allah yang berkarya. Gereja melalui pelayanan pastoralnya hendaknya mampu menyentuh orang-orang yang sedang mengalami krisis makna hidup itu.

\section{Kematian sebagai Belas Kasih Allah}

Tidak ada seorang pun dapat dipisahkan dari kasih Allah, bahkan oleh kematian itu sendiri. Kalau kematian adalah pengalaman universal, yakni realitas yang pasti terjadi dan tidak ada yang bisa menolaknya, maka bagaimana belas kasih Allah dapat dijumpai dalam pengalaman kematian? Belas kasih Allah nampak dalam pemberian diri-Nya kepada manusia yang berpuncak dalam diri Yesus Kristus melalui misteri inkarnasi. Sedangkan pemberian diri Allah yang paling radikal terwujud dalam keinginan-Nya untuk mau mengalami kematian yang sama seperti manusia. Dengan kata lain, kematian Yesus Kristus adalah bentuk kasih Allah yang paling nyata kepada manusia. Melalui kematian Kristus, Allah tidak saja mengalami kegelapan dan ketidakjelasan, tetapi juga turut merasakan kepedihan, kemarahan, ketidakberdayaan, ketakutan, dan kerapuhan manusia.

Dalam tradisi kristiani pemahaman akan kematian juga tidak dapat dipisahkan dari peristiwa kebangkitan Kristus dari alam maut. Bagaimanapun juga, paham kristiani mengenai kematian tidak berhenti pada kematian dan absurditasnya sebagai akhir dari kehidupan, tetapi sampai pada keyakinan dan harapan akan kebangkitan. Jika kebangkitan berhubungan erat dengan seluruh pribadi manusia sebagai kesatuan jiwa dan badan, maka mereka yang mati di dalam Kristus akan dibangkitkan juga di dalam iman. Kebangkitan Yesus merupakan perwujudan dari apa yang dilakukan-Nya 
di dunia, khususnya penyerahan diri-Nya kepada kehendak Allah. Dengan demikian, harapan akan kebangkitan menempatkan hubungan yang eksistensial antara manusia dengan kasih Allah dalam seluruh pengalaman hidupnya sehari-hari yang disempurnakan melalui kematian.

Sebaliknya, pada masa milenial ini kita hidup di tengah dunia "di mana nama Allah kadang-kadang dikaitkan dengan balas dendam atau bahkan tindakan kebencian dan kekerasan" (DCE 1). Ketika berhadapan dengan pengalaman kematian, baik yang disebabkan oleh peristiwa natural, maupun oleh karena bencana, kecelakaan, kekerasan, dan sakit berat, manusia lebih mudah melihat kematian sebagai hukuman Allah daripada sebagai bentuk belas kasih Allah. Akibatnya, hidup menjadi tidak bebas karena dibelenggu oleh rasa takut akan kematian dan hukuman di akhirat. Apalagi ditambah dengan keyakinan agama yang lebih menekankan tentang siksaan neraka akan menambah ketakutan seseorang akan kematian. Di sisi lain, mereka justru menyingkirkan Allah dari kehidupan manusia. Mereka memilih untuk tidak bergantung pada Allah tetapi bergantung pada diri mereka sendiri. Pandangan semacam ini justru membuat orang mudah membenci kehidupan bahkan memandang kehidupan yang lain tidak bernilai. Sikap semacam ini yang kemudian menjadi dasar dan alasan untuk melakukan bunuh diri, euthanasia, aborsi, melegalkan hukuman mati, kekerasan dan perang.

Gereja percaya bahwa Allah adalah kasih dan Yesus Kristus adalah wajah kerahiman Allah (MV 1). Pemikiran Rahner mengenai kematian sebagai belas kasih Allah dapat menjadi penegasan bahwa kasih Allah melampaui kematian. Sebagaimana dika- takan di atas bahwa melalui kasih-Nya, Yesus memilih untuk menempatkan diri-Nya di bawah "hukuman" Allah dan dalam kasihNya pula Ia menerima "hukuman" itu. Dengan berpegang pada ajaran ini, Gereja tidak henti-hentinya menyuarakan kasih Allah ini dengan merangkul mereka yang membenci kehidupan. Memperjuangkan kehidupan dan menolak tindakan yang merendahkan martabat manusia seperti bunuh diri, euthanasia, hukuman mati, kekerasan dan perang. Sebab, dengan merangkul kehidupan, rasa takut akan kematian akan berkurang karena orang jadi menghargai hidupnya sendiri dan belajar menerima bahwa kematian itu sesuatu yang alami.

\section{Menghayati Kematian dalam Kehidupan}

Salah satu ciri masyarakat milenial adalah sikap pragmatis, mau cepat dan tidak mau repot. Pandangan ini kerap kali mendorong orang untuk melihat kematian sebagai sarana untuk lari dari penderitaan hidup. Karena itu, muncul fenomena bunuh diri dan euthanasia yang didasari oleh cara pandang semacam ini. Padahal, menurut pandangan kristiani, kematian merupakan sesuatu yang dinantikan dan bukannya diciptakan. Lalu bagaimana hal ini dapat dijelaskan?

Dalam berhadapan dengan realitas kematian, bagaimanapun juga manusia harus siap untuk meninggalkan dan ditinggalkan. Dalam hal ini, Yesus sendiri dapat menjadi contoh yang istimewa tentang bagaimana Ia mengalami peristiwa yang sama seperti kita. Oleh karena itu, manusia selayaknya menyongsong kematian dengan keyakinan akan kebangkitan bersama Kristus. Sebab "andaikata Kristus tidak dibangkitkan, maka sia-sialah pemberitaan kami dan sia-sialah juga kepercayaan kamu" (1 Kor 15:14). 
Di kota besar seperti Jakarta yang sarat dengan gaya hidup materialistis, konsumeristis, dan individualistis, orang cenderung berpikir tentang hal-hal duniawi. Seluruh hidup mereka diisi untuk mengusahakan bagaimana orang dapat hidup sukses dan menjadi kaya. Mereka lupa bahwa kehidupan ini hanya sementara dan akan berakhir dengan kematian. Tingginya sikap individualistis juga turut mempengaruhi seseorang dalam menghadapi kematian. Orang yang sepanjang hidupnya bergantung pada diri sendiri biasanya tidak siap untuk menjadi lemah dan tidak berdaya. Mereka berusaha menjaga agar hidupnya tetap produktif sehingga menghalangi mereka untuk berpikir tentang kematian. Pada akhirnya, rasa takut akan kematian akan mempengaruhi baik secara psikologis maupun secara emosional. ${ }^{56}$

Orang yang sedang menderita karena sakit berat juga mudah menjadi takut akan kematian. Ketidakberdayaan karena sakit berat dapat dengan mudah membuat orang merasa ditinggalkan dan terasing dari dunia. Mereka menjadi kesepian dan merasa diri tidak berguna. Akibatnya, alih-alih bertahan dengan penderitaannya, orang cenderung menyerah kalah dan memilih untuk menghindari penderitaan melalui euthanasia. Dalam situasi dan kondisi semacam inilah Gereja memiliki peranan yang amat besar dalam mendampingi orang-orang yang putus asa dan kesepian karena sakit berat. Tidak hanya pendampingan untuk pasien, pendampingan bagi keluarga pasien juga dibutuhkan sehingga dapat menjadi sarana pewartaan yang baik.

\section{KESIMPULAN}

Hipotesis pada awal tulisan ini adalah membuktikan bahwa kematian kristiani dalam pemikiran Rahner dapat dimaknai se- bagai belas kasih Allah. Melalui tulisan-tulisan Rahner, penulis menyimpulkan bahwa realitas kematian dalam iman kristiani mesti dimaknai dalam kesatuannya dengan cinta kasih Allah sendiri yang ditunjukkan melalui wafat dan kebangkitan Putra-Nya, Yesus Kristus. Pernyataan tesis ini dapat dibuktikan dengan beberapa dasar dan kesimpulan sebagai berikut:

1. Kekhasan teologi Rahner ialah menempatkan komunikasi diri Allah (Selbstmitteilung Gottes) sebagai pusat pemikirannya. Komunikasi diri Allah itu mewujud dalam rupa Allah-Putra sehingga setiap orang yang percaya kepada-Nya dapat beroleh belas kasih Allah yang sama. Demikian pula dalam merefleksikan tentang kematian, pemberian diri Allah ini ada di dalamnya, sehingga dalam kematian sekalipun setiap orang tetap dapat menemukan belas kasih Allah ini. Melalui pemikiran Rahner, penulis menemukan bahwa belas kasih Allah ini nampak dalam pemberian diri-Nya kepada manusia yang berpuncak dalam diri Yesus Kristus melalui misteri inkarnasi. Dan belas kasih Allah yang berpuncak pada Yesus Kristus ini mewujudkan pemberian diri-Nya yang paling radikal dengan mau ambil bagian dalam kematian Yesus. Dengan demikian, tidak ada seorang pun yang dapat dipisahkan dari kasih Allah sendiri, bahkan oleh kematian sekalipun.

2. Karl Rahner menekankan bahwa berbicara tentang realitas kematian tidak bisa tidak mengandaikan iman akan Yesus Kristus yang bangkit. Hanya iman yang dapat menjawab misteri kematian dan kehidupan di seberang kematian. Tanpa iman akan Kristus yang bangkit, berbicara mengenai kematian hanya akan dipandang sebagai kematian tubuh dan musnahnya kehidupan. Kebangkitan ha- 
nya menjadi imajinasi dan kehidupan kekal hanya menjadi harapan palsu semata. Demikianlah Rahner berpegang pada iman dan harapan akan kebangkitan, meskipun misteri kematian sendiri melampaui uraian yang disampaikannya.

3. Kematian adalah jalan keselamatan. Dengan ambil bagian dalam kematian Kristus, setiap umat kristiani dipanggil untuk ambil bagian dalam keselamatan universal. Kematian Kristus telah mengubah makna kematian manusia bukan lagi sebagai hukuman atas dosa, melainkan sebagai partisipasi dalam kasih Allah yang ingin menyelamatkan manusia. Seluruh karya keselamatan Allah selalu mengarah pada kesempurnaan dan bersifat universal. Oleh karena itu, keselamatan universal merupakan perwujudan belas kasih Allah yang mengalir di sepanjang kehidupan manusia. Kematian adalah penyelesaian definitif dari proses kebebasan manusia dalam menjawab kasih Allah itu. Dengan ambil bagian dalam kematian Kristus, orang kristiani turut

\section{CATATAN AKHIR}

Karl Rahner, On The Theology of Death, diterjemahkan oleh Charles H. Henkey (New York: Herder and Herder, 1962), 64

2 F. Budi Hardiman, Seni Memahami: Hermeneutik dari Schleiermacher sampai Derrida (Jakarta: Penerbit Kanisius, 2015), 145.

3 F. Budi Hardiman, Seni Memahami: Hermeneutik dari Schleiermacher sampai Derrida, 164.

4 Dalam menuliskan biografi Karl Rahner, penulis mengambil data-data dari berbagai sumber pustaka. Namun untuk berbagai data-data yang lebih rinci penulis berpatokan pada buku William Dych, Karl Rahner (London: Continuum, 2000).

5 William Dych, Karl Rahner, 4.

6 James C. Livingston, Modern Christian Thought, Vol. 2, 200. Joseph Maréchal lahir di Charleroi, Belgia. Pada tahun 1895 ia masuk Yesuit dan belajar filsafat skolastik di University of Louvain.

7 James C. Livingston, Modern Christian Thought, Vol. 2, 200. Pierre Rousselot adalah salah satu tokoh berpengaruh dalam nouvelle théologie yang mencoba menyoroti aspek iman yang diabaikan atau ditolak oleh neo-skolastik.

8 William Dych, Karl Rahner, 5.

9 William Dych, Karl Rahner, 9.

10 William Dych, Karl Rahner, 15. serta dalam karya keselamatan Allah sendiri dan memperoleh kesempurnaan di dalam-Nya. Dengan demikian, kematian kristiani dapat dimaknai sebagai puncak belas kasih Allah karena manusia disempurnakan di dalam Kristus bahkan di saat terakhir dan ketidakberdayaan hidupnya.

Melalui pembahasan terhadap tema tentang kematian, penulis melihat kekayaan dari pemikiran Rahner tentang teologi transendental yang dikembangkannya. Penulis menilai bahwa teologi Rahner bagaimanapun juga dapat dijadikan dasar bagi pemikiran teologi saat ini. Melalui teologi tentang kematian yang berorientasi pada transendensi manusia, diharapkan teologi Rahner mampu memberikan andil bagi penghayatan iman umat dalam memaknai realitas kematian secara kontekstual sekaligus kristiani. Dengan demikian, pemikiran Rahner tentang kematian tetap dapat memberikan pengaruh yang selaras dengan tuntutan dan perkembangan zaman.

11 Eddy Kristiyanto, Reformasi dari Dalam: Sejarah Gereja Zaman Modern, 189. Enlightenment pertama kali berkembang di Inggris dan Belanda. Enlightenment kemudian menyebar di Prancis melalui pemikiran Voltair dan memuncak di Jerman oleh pemikiran beberapa filsuf, seperti Immanuel Kant dan Leibniz.

12 Eddy Kristiyanto, Reformasi dari Dalam: Sejarah Gereja Zaman Modern, 207.

13 Emiliana P. Noether, "Vatican Council I: Its Political and Religious Setting" dalam The Journal of Modern History, Vol. 2, 1968: 2, 218-233.

14 Jeremy Morris, The Church in the Modern Age, 27.

15 Hubert Jedin, History of The Church Vol IX: The Church in the Industrial Age, 307.

16 Louis Leahy, Misteri Kematian, 33.

17 Karl Rahner, "Christian Dying”, TI 18 (London: Darton Longman \& Todd Ltd., 1984), 228.

18 Karl Rahner, "On Christian Dying", $T I$ 7, 286.

19 Bdk. Karl Rahner, On The Theology of Death (New York: Herder and Herder, 1962),21. "Death is an event which strikes man in his totality"

20 Karl Rahner, On The Theology of Death, 21. "The universality of death is an absolute proposition of our faith." Karl Rahner, On The Theology of Death, 22.

22 Karl Rahner, On The Theology of Death, 21. "Death is an event which strikes man in his totality." 
JURNAL TEOLOGI, 08.01 (2019): 47-64

23 Karl Rahner, "The Unity of Spirit and Matter in the Christian Understanding of Faith", TI 6, 160.

24 Karl Rahner, "Theological Considerations Conserning the Moment of Death", TI 11, 317.

25 Karl Rahner, On The Theology of Death, 65. "The word of God, through the incarnation in the womb of the Virgin, became consubstantial with us. From this it follows that, in a real sense, Christ died our death. He suffered the death of the human race fallen in Adam... But if he really became one of us in everything but sin, as the Epistle to the Hebrews says, then he became like us in death too."

26 Karl Rahner, On The Theology of Death, 64. Karl Rahner mengatakan bahwa " death is not only a manifestation of sin, but also a revelation of our participation in the death of Christ, culminating in the appropriation of his redemptive death by mortal sin."

27 Karl Rahner, On The Theology of Death, 69. "The redeeming act of Christ will not reside his death as such, but more precisely in his patient and obedient submission to the suffering which caused his death... He not only offered satisfaction for sin, but he enacted and suffered death as death is the expression, the manifestation and the revelation of sin in the world."

28 Karl Rahner, On The Theology of Death, 75-80.

29 Karl Rahner, On The Theology of Death, 68.

30 Karl Rahner "Christian Dying", TI18, 254. "Grace consists fundamentally in God's self-communication to enable man in freedom by faith, hope, and love to accept the immediacy to God that is offered to him."

31 Karl Rahner, Foundations of Christian Faith, 122.

32 Hans-Georg Gadamer, Truth and Method (New York: The Seabury Press, 1975), 319. "experience here is something that is part of the historical nature of man."

33 Hans-Georg Gadamer, Truth and Method, 320.

34 Hans-Georg Gadamer, Truth and Method, 320. "Thus experience is experience of human finitude. The truly experienced man is one who is aware of this, who knows that he is master neither of time nor the future. The experienced man knows the limitedness of all prediction and the uncertainty of all plans. In him is realized the truth-value of experience. If it is characteristic of every phase of the process of experience that the experienced person acquires a new openness to the new experiences, this is certainly true of the idea of complete experience".

35 Hans-Georg Gadamer, Truth and Method, 320. "Real experience is that in which man becomes aware oh his finiteness. In it are discovered the limits of the power and the self-knowledge of his planning reason."

36 Hans-Georg Gadamer, Truth and Method, 319. Bagi Gadamer pengalaman senantiasa dapat dipelajari karena dengan berhadapan dengan pengalaman itu, seseorang mampu terbuka terhadap pengalaman yang didorong oleh pengalaman itu sendiri. Ia mengatakan: "The truth of experience always contains an orientation towards new experience... because of the many experiences he has had and the knowledge he has drawn from them is particulary well equipped to have new experiences and to learn from them. The dialectic of experience has its own fulfillment not in definitive knowledge, but in that openness to experience that is encouraged by experience itself."

37 Hans-Georg Gadamer, Truth and Method, 320. "Real experience is that in which man become aware of his finiteness. In it are discovered the limits of the power and the self-knowledge of his planning reason. It proves to be an illusion that everything can be reserved, that there is always time for everything and that everything somehow returns."
38 Allison Pond, dkk, Religion among the Mellennials, 1. Pemberian nama pada setiap generasi merupakan hasil dari sebuah budaya populer. Beberapa digambarkan berdasarkan dari sebuah peristiwa sejarah, perkembangan sosial, maupun perubahan demografi; lainnya dapat berasal dari perubahan besar di dalam kalender.

39 Allison Pond, dkk, Religion among the Mellennials, 4.

40 Gerarld Philips, Introduction to Secularism, 6. "One of the strongest selling points of secularism is that, by separating religion from the state, it protects every person's freedom to choose what to believe or what not believe, within the law. This protects religious people from other religious people, as well as from people whose beliefs are not religious. And vice-versa. Secularism advocates that the state should not be involved in matters of religion and religion should not be involved in matters of the state."

$41 \quad$ Paul James, "Globalizing Consuption and the Deferral of a Politics of Consequence" dalam Globalizations Vol.9, 234.

42 Leslie Sklair, Globalization: Capitalism and its Alternatives (Oxford: Oxford University Press, 2002.), 36.

43 Fulton Sheen, Hidupmu Layak Dihidupi (Yogyakarta: Kanisius, 2017), 391

44 Zachary Hayes, Theology of Death, 10. "The idea of conquering death through technology, with all the problems that this has created, personal, legal, and medical. Death is perceived almost as an affront to the capabilities of our highly technological culture."

45 Zachary Hayes, Theology of Death, 10. "Death is perceived almost as an affront to the capabilities of our highly technological culture. So the common temptation is to use whatever means are available to prolong life regardless of the eventual outcome."

46 https://databoks.katadata.co.id/datapublish/2018/01/24/ berapa-jumlah-penduduk-jakarta (diunduh pada $20 \mathrm{Ma}-$ ret 2018). Jumlah penduduk DKI Jakarta ini berdasarkan data terakhir per 1 Januari 2018 dari Badan Pusat Statistik.

47 h t t p s://finance.detik. com/berita-ekonomi-bisnis/2181083/jakarta-kuasai-70-perputaran-uang-sayangnya-kesenjangan-tinggi (diunduh pada 20 Maret 2018). Ketua Umum Kamar Dagang dan Industri (Kadin) Indonesia, Suryo Bambang Sulisto mengungkapkan bahwa 70\% perputaran uang di Indonesia terjadi di Jakarta.

48 Beberapa tantangan ini merupakan hasil Sinode Keuskupan Agung Jakarta tahun 1990 yang sampai pada saat ini, walaupun dengan beberapa tambahan, masih menjadi acuan dalam merancang ARDAS 2016. Menggereja di Jakarta dan Sekitarnya Pada Tahun 2000, 33-35.

49 Dominic Strinati, Popular Cultur: Pengantar Menuju Budaya Populer (Yogyakarta: Narasi-Pustaka Promethea, 2016),287.

50 Karl Rahner "On Christian Dying”, TI 7, 285. "In what we shall be saying about death here we shall be taking it not in the strictly biological or physiological sense of the term, but rather in that sense which it bears in the context of the Christian understanding of human existence."

$51 \quad$ Karl Rahner "On Christian Dying", TI 7, 285. "This is not because the latter is in contradiction to the former, but rather because precisely as person endowed with freedom and with spiritual powers man is more than a biological 'case'."

52 Karl Rahner, Theology of Death, 43.

53 Karl Rahner "On Christian Dying", TI 7, 286. "The primary factor to which the christian understanding of death directs our attention is the universality of death." 
$54 \quad$ Karl Rahner, Foundations of Christian Faith,435.

55 Lih. "Transcendental Theology" dalam Sacramentum Mundi Vol.6, 287. "The problem of transcendental theology is also the special and authentically theological question, as to whether a transcendental enquiry into

\section{DAFTAR RUJUKAN}

Allison, P., Gregory Smith, dan Scott Clement., "Religion among the Millennials" dalam Pew Forum on Religion \& Public Life, 2010.

Dych, W. KarlRahner. London: Continuum, 2000.

Hardiman, F. Budi. Seni Memahami: Hermeneutik dari Schleiermacher Sampai Derrida. Jakarta: Penerbit Kanisius,2015.

James, P. "Globalizing Consuption and the Deferral of a Politics of Consequence", dalam Globalizations, Vol. 9, 2012, 225-240.

Jedin, H. History of The Church Vol IX: The Church in the Industrial Age. London: Burns \& Oates, 1981.

History of The Church Vol X: The Church in the Modern Age. London: Burns \& Oates, 1981.

Kristiyanto, E. Reformasi dari Dalam. Yogyakarta: Penerbit Kanisius, 2004.

Leahy, L.Misteri Kematian: Suatu Pendekatan Filosofis. Jakarta: Gramedia Pustaka Utama, 1996.

Livingston, James C.Modern Christian Thought, Vol. 2. Minneapolis: Fortress Press, 2006.

Gadamer, Hans-Georg. Truth And Method. New York: The Seabury Press, 1975.

Morris, J.The Church in the Modern Age. London: I. B. Tauris, 2007..

Noether, E.P. "Vatican Council I: Its Political and Religious Setting", dalam The Journal of Modern History, Vol. 2, No. 2, Chicago: The University of Chicago Press, 1968, 218-233. the conditions of possibility of knowledge in the subject himself can be envisaged with regard to an object of revelation and faith."

56 Bdk. Agustine Dwiputri, "Takut akan Kematian" dalam Kompas, Sabtu, 17 Februari 2018.

Rahner, K. Foundations of Christian Faith: An Introduction to the Idea of Christianity, diterjemahkan oleh William V. Dych. New York: Seabury. [Grundkurs des Glaubens: Einführung in den Begriff des Christentums (Freiburg: Herder, 1976).]

On The Theology of Death, diterjemahkan oleh Charles H. Henkey.New York: Herder and Herder. [Zur Theologie des Todes (Freiburg: Herder, 1961).]

.Sacramentum Mundi Vol 1-6, London: Burn \& Oates, 1970.

.Spirit in The World, diterjemahkan oleh William V. Dych. New York: Herder and Herder, 1968.

Sheen, F.J. Hidupmu Layak Dihidupi. Yogyakarta: Penerbit Kanisius, 2017.

Sklair, L. Globalization: Capitalism and its Alternatives. Oxford: Oxford University Press, 2002.

Philips, G. Introduction to Secularism. London: National Secular Society, 2011.

Strinati, D. Popular Cultur: Pengantar Menuju Teori Budaya Populer. Yogyakarta: Narasi-Pustaka Promothea, 2016.

Dister, Nico Syukur. Teologi Sistematika 2. Yogyakarta: Kanisius, 2004.

Aubert, R. The Christian Centuries Vol. 5: The Church in a Secularised Society. London: Darton, Longman \& Todd Ltd, 1978.

Phan, P.C. Eternity in Time: A Study of Karl Rahner's Eschatology. Selinsgrove: Susquehanna University Press, 1988. 
